\title{
Original Research Radiology \\ Assessment of skeletal and dental ages of children and adolescents with type 1 Diabetes Mellitus
}

\section{Ilana Sanamaika Queiroga BEZERRA $^{(a)}$ \\ Francielle TOPOLSKI(a) \\ Suzana Nesi FRANÇA(b) \\ Márcia Rejane BRÜÇKER ${ }^{(c)}$ \\ Ângela FERNANDES(a)}

\footnotetext{
(a) Universidade Federal do Paraná - UFPR, School of Dentistry, Department of Stomatolgy, Curitiba, PR, Brazil.

(b) Universidade Federal do Paraná - UFPR, School of Medicine, Department of Pediatric Endocrinology, Curitiba, PR, Brazil.
}

(c)Pontifícia Universidade Católica do Rio Grande do Sul - PUCRS, School of Dentistry, Department of Surgery, Porto Alegre, RS, Brazil.

Declaration of Interests: The authors certify that they have no commercial or associative interest that represents a conflict of interest in connection with the manuscript.

\section{Corresponding Author:}

Ilana Sanamaika Queiroga Bezerra E-mail: sanamaika@yahoo.com.br

DOI: 10.1590/1807-3107BOR-2015.vol29.0025

Submitted: Mar 11, 2014

Accepted for publication: Oct 15, 2014

Last revision: Dec 05, 2014

\begin{abstract}
The present study aimed to assess the skeletal and dental ages of type 1 diabetes mellitus (T1DM) patients. Therefore, panoramic and hand-wrist radiographs of 82 patients, aged between 5 and 15 years, were collected and divided into case and control groups. The case group consisted of 41 panoramic and 41 hand-wrist radiographs of T1DM patients, whereas the control group consisted of 41 panoramic and 41 hand-wrist radiographs of patients without T1DM. Skeletal age was assessed according to the method of Greulich and Pyle (1999), whereas dental age was assessed according to the method of Nolla (1960). Chi-square tests revealed no statistically significant differences between skeletal and dental ages between the case and control groups $(p>0.05)$. However, in the case group, the skeletal age of females was greater than that of age-matched males $(p=0.005)$. Considering that skeletal and dental growth of the case and control groups were closely related, clinical interventions involving orthodontics and dentomaxillofacial orthopedics should be equally performed both for healthy and specific patient groups, such as those with T1DM.
\end{abstract}

Keywords: Diabetes Mellitus, Type 1; Child Development; Adolescent Development; Age Determination by Skeleton; Age Determination by Teeth.

\section{Introduction}

Type 1 diabetes mellitus (T1DM) is a metabolic disease characterized by recurrent or persistent hyperglycemia, resulting from the progressive impairment of insulin secretion, ${ }^{1}$ with an increasing prevalence among younger individuals worldwide., ${ }^{2,3}$ The major sequelae of T1DM include dysfunction of several organs, such as that of the kidneys, eyes, and heart. ${ }^{1}$ In addition, T1DM patients are eventually affected by growth and developmental disorders. ${ }^{4}$ Thus, chronological age may not be an appropriate indicator of maturity in T1DM patients, ${ }^{5,6}$ making it necessary to investigate biological variables, such as the skeletal and dental development. ${ }^{6,7,8}$

Comparative studies of skeletal age to chronological age have reported both over- and underestimation of the age of T1DM patients.,10,11,12 To the best of our knowledge, there have been no studies comparing the dental age of T1DM patients. However, the usefulness of implementing information related to dental age in surveys on skeletal age has shown that dental age is strongly 
related to genetic variables, ${ }_{1}^{13}$ whereas skeletal age is more sensitive to environmental influence. ${ }^{14}$ Thus, the use of both skeletal and dental ages can optimize investigations that include the biological age ${ }^{15}$ of T1DM patients.

In this context, the present study was undertaken to separately investigate the usefulness of skeletal and dental ages of T1DM patients in comparison with chronological age to facilitate clinical planning of orthodontic and orthopedic interventions and dentomaxillofacial surgeries.

\section{Methodology}

The present study was approved by the Committee of Ethics in Research at the Universidade Federal do Paraná - UFPR, Brazil, under the protocol no \#0028.0.208.000-11. The study cohort consisted of 82 panoramic and hand-wrist radiographs of 30 male and 52 female Brazilian patients, aged between 5 and 15 years. This cohort was divided into gender- and age-matched case and control groups. The case group consisted of 41 hand-wrist and panoramic radiographs of T1DM patients who underwent treatment at the Pediatric Endocrinology Department of the Hospital de Clinicas, Curitiba. The control group consisted of 41 panoramic and hand-wrist radiographs of patients without T1DM who received dental services at the Dentistry School of the Pontifícia Universidade Católica do Rio Grande do Sul. Only high quality radiographs were included in this study. In addition, patients presenting with missing teeth and other systemic diseases or diagnosed and treated for T1DM less than 2 years before the start of this study were excluded.

All the radiographs were obtained using the Ortophos ${ }^{\circledR}$ CD radiologic device (Siemens AG, Munich, Germany). The radiographs were automatically processed and digitalized to $150 \mathrm{dpi}$ in standard form utilizing a HPScanjet ${ }^{\circledR}$ G4050 scanner (HewlettPackard, Palo Alto, USA). To prevent bias, identification radiograph data was masked and the images were saved in the Tagged Image File Format. Three longterm experienced dentomaxillofacial radiologists interpreted the images. Skeletal age was assessed using the method of Greulich and Pyle, ${ }^{16}$ whereas dental age was assessed using to the method of Nolla. ${ }^{17}$

Twenty panoramic and hand-wrist radiographs were used for calibration by the three examiners.
The images were analyzed three times within a 15-day interval between each interpretation. Intraand inter-examiner agreement was calculated using Kappa statistics. After calibration, the examiners evaluated each image three times with a 3-day interval between each interpretation. The average of each individual interpretation was considered to represent the estimations of skeletal and dental age.

For statistical analysis, the collected data were transformed into categorical variables. The estimated skeletal and dental ages were compared to the chronological age of each patient and further divided into three categories: (1) delayed development (biological age < chronological age); (2) perfect match (biological age $=$ chronological age); and (3) advanced development (biological age > chronological age). All statistical analyses were performed using the Software Package for the Social Sciences (SPSS ${ }^{\circledR}$ ) version 15.0 (SPSS Inc., Chicago, USA), and the data were evaluated using the chi-square test. A $p$ value of $\leq 0.05$ was considered statistically significant.

\section{Results}

Intra- and inter-examiner agreement of greater than 0.81 by Kappa statistics indicated a sufficient coefficient of calibration. There were no statistically significant differences between skeletal $(p=0.71)$ and dental $(p=0.10)$ ages between the case and control groups (Table 1). However, female T1DM patients showed significantly $(p=0.005)$ advanced skeletal development compared to male T1DM patients (Table 2).

Table 1. Distribution of skeletal and dental ages of patients with and without T1DM in relation to chronological age.

\begin{tabular}{lccc}
\hline Age & $\begin{array}{c}\text { With T1DM } \\
\mathrm{n}(\%)\end{array}$ & $\begin{array}{c}\text { Without T1DM } \\
\mathrm{n}(\%)\end{array}$ & $\mathrm{p}^{*}$ \\
\hline $\begin{array}{l}\text { Skeletal } \\
\quad \text { Delayed development }\end{array}$ & $14(34.3)$ & $14(34.1)$ & 0.71 \\
$\quad \begin{array}{l}\text { Perfect match } \\
\text { Advanced development }\end{array}$ & $12(29.3)$ & $15(36.6)$ & \\
Dental & & $12(29.3)$ & \\
$\quad$ Delayed development & $13(31.7)$ & $16(39.0)$ & \\
$\quad \begin{array}{l}\text { Perfect match } \\
\text { Advanced development }\end{array}$ & $20(48.8)$ & $11(26.9)$ & \\
\hline
\end{tabular}

${ }^{*}$ Chi-squared test. Significance level of $5 \%$. 
Table 2. Distribution of dental and skeletal ages among male and female patients in the case and control groups in relation to chronological age.

\begin{tabular}{|c|c|c|c|c|c|c|c|}
\hline \multirow[b]{2}{*}{ Group } & \multirow[b]{2}{*}{ Outcome } & \multicolumn{3}{|c|}{ Dental age } & \multicolumn{3}{|c|}{ Skeletal age } \\
\hline & & $\begin{array}{l}\text { Male } \\
\mathrm{n}(\%)\end{array}$ & $\begin{array}{c}\text { Female } \\
\mathrm{n}(\%)\end{array}$ & $p^{*}$ & $\begin{array}{l}\text { Male } \\
\mathrm{n}(\%)\end{array}$ & $\begin{array}{c}\text { Female } \\
\mathrm{n}(\%)\end{array}$ & $p^{*}$ \\
\hline \multirow[t]{3}{*}{ Case } & Advanced development & $2(13.3)$ & $6(23.1)$ & 0.74 & $1(6.7)$ & $14(53.8)$ & 0.005 \\
\hline & Delayed development & $5(53.3)$ & $8(30.8)$ & & $6(40.0)$ & $8(30.8)$ & \\
\hline & Perfect match & $8(53.3)$ & $12(46.2)$ & & 8 (53.3) & $4(15.4)$ & \\
\hline \multirow[t]{3}{*}{ Control } & Advanced development & $4(26.7)$ & $10(38.5)$ & 0.09 & $4(26.7)$ & $8(30.8)$ & 0.93 \\
\hline & Delayed development & $4(26.7)$ & $12(46.2)$ & & $5(33.3)$ & $9(34.6)$ & \\
\hline & Perfect match & $7(46.7)$ & $4(15.4)$ & & $6(40.0)$ & $9(34.6)$ & \\
\hline
\end{tabular}

* Chi-square test. Significant results $(p>0.05)$ are indicated in black.

\section{Discussion}

The results of the present study revealed no differences between skeletal and dental development between T1DM and control patients. The same was observed in a study reported by Birkbeck ${ }^{18}$ in 1972, which described the influence of medical treatment on developmental delay of T1DM patients. Similarly, Thon et al. ${ }^{11}$ detected no statistical differences between skeletal age of healthy children and that of T1DM patients. On the other hand, Holl et al. ${ }^{10}$ observed no significant difference between skeletal age and biological age at the onset of T1DM. However, during the progression of T1DM, a trend of delayed skeletal development was detected. Therefore, the precise timing for T1DM treatment is particularly relevant in children in the prepubertal and pubertal periods, when human development is noticeably accelerated. Similarly, Dost et al. ${ }^{9}$ reported delayed skeletal development with respect to the biological and chronological ages in a large sample of children and adolescents with T1DM. Despite these results, the absence of a control group hampered optimal analysis of the biological development of T1DM patients. Nevertheless, in the present study, the implementation of a control group, which was individually matched by gender and age to the case group, was essential for the scientific and systematic research design to support our results.

Moreover, the significantly advanced skeletal age of females with T1DM, as compared with that of males, was a secondary outcome of this study. Similar results were observed by Ahmed et al. ${ }^{12} \mathrm{a}$ decrease in the levels of sex steroid binding proteins in female patients was observed. Consequently, the level of free steroids was greater in females, thereby promoting interactions with target organs and skeletal development. In addition, weight gain in T1DM is more noticeable in females, corroborating this previous theory. ${ }^{19,20}$ According to Dost et al. ${ }^{9}$ and Songer et al., ${ }^{21}$ weight gain is also a common result in the prepubertal period, which culminates in bone maturation and consequent advanced skeletal age.

Moreover, the present study is the first scientific investigation of dental age in T1DM patients. However, no statistically significant differences were detected between the case and control groups. Dental age is an important variable for investigations utilizing biological age of T1DM patients because it is more sensitive to systemic disorders than skeletal age, ${ }^{13}$ which is highly influenced by environmental factors. ${ }^{6,22,23}$ Vallejo-Bolaños and España-López ${ }^{24}$ examined the skeletal and dental ages of 54 children with growth disorders and reported that skeletal age was delayed by 23 months and dental age by 12 months as compared with the chronological age. In addition, similar outcomes were verified in a 1980 study by Ozerovic, ${ }^{25}$ where the same developmental variables in 109 patients with cerebral palsy were evaluated. Despite these results, longitudinal follow-ups are encouraged for a deeper and more accurate investigation of the influence of systemic disorders in the course of dental development.

In a parallel context, dental age estimations are often performed for forensic reasons, such as the determination of age of legal majority and capacity and the identification of unaccompanied 
minors, illegal immigrants, and unknown bodies. ${ }^{14}$ However, techniques for the estimation of dental age are calibrated against distinct populations of healthy individuals but rarely validated in specific populations, such as T1DM patients. ${ }^{14}$ The present study validated the technique of Nolla ${ }^{17}$ both in healthy and specific patient groups, which resulted in a statistically significant similarity, indicating that the referred technique is applicable and reliable even for unique forensic cases involving T1DM patients and investigations for legal reasons.

\section{Conclusion}

Based on these outcomes, the present study indicated that T1DM does not seem to impact dental and hand-wrist bone development of children and adolescents. Therefore, clinical interventions, which particularly involve orthodontics and

\section{References}

1. American Diabetes Association. Diagnosis and classification of diabetes mellitus. Diabetes Care. 2004 Jan;27 Suppl 1:S5-10.

2. Diamond Project Group. Incidence and trends of childhood type 1 diabetes worldwide 1990-1999. Diabet Med. 2006 Aug;23(8):857-66.

3. Karvonen M, Viik-Kajander M, Moltchanova E, Libman I, LaPorte R, Toumilehto J. Incidence of childhood type 1 diabetes worldwide. Diabetes Care. 2000 Oct;23(10):1516-26.

4. Chiarelli F, Giannini C, Mohn A. Growth, growth factors and diabetes. Eur J Endocrinol. 2004 Nov;151Suppl 3:U109-17.

5. Cardoso H. Differential sensitivity in growth and development of tissue to environmental quality. Arq Med. 2007 Jan;21(1):19-23.

6. Kurita LM, Menezes AV, Casanova MS, Haiter-Neto F. Dental maturity as an indicator of chronological age: radiographic assessment of dental age in a brazilian population. J Appl Oral Sci. 2007 Apr;15(2):99-104.

7. Fishman LS. Maturational patterns and prediction during adolescence. Angle Orthod. 1987 Jul;57(3):178-93.

8. Martin DD, Wit JM, Hochberg Z, Sävendahl L, van Rijn RR, Fricke $\mathrm{O}$, et al. The use of bone age in clinical practice - Part 1. Horm Res Paediatr. 2011;76(1):1-9.

9. Dost A, Rohrer T, Fussenegger J, Vogel C, Schenck B, Wabistch $\mathrm{M}$, et al. Bone maturation in 1788 children and adolescents with diabetes mellitus type 1. J Pediatr Endocrinol Metab. 2010 Sep;23(9):891-8.

10. Holl RW, Heinze E, Seifert M, Grabert M, Teller WM. Longitudinal analysis of somatic development in paediatric pa- dentomaxillofacial orthopedics, may be equally applied to both healthy individuals and T1DM patients. However, we acknowledge the valuable role of longitudinal case-control surveys and longterm follow-ups to support our results. In addition, we encourage future investigations of the interface between bone development and prevalence of T1DM in children to test the potential bias of mineral density in age estimation studies.

\section{Acknowledgments}

The authors would like to thank Professors Aguinaldo Nascimento, Mônica Lima, Antônio Adilson Soares de Lima, and Fernando Henrique Westphalen of the Universidade Federal do Paraná UFPR as well as Gabriela Cristina Santin and Thais Matheus for their contributions to this study.

tients with IDDM: genetic influences on height and weight. Diabetologia. 1994 Sep;37(9):925-9.

11. Thon A, Heinze E, Feilen KD, Holl RW, Schmidt H, Koletzko $S$, et al. Development of height and weight in children with diabetes mellitus: report on two prospective multicentre studies, one cross-sectional, one longitudinal. Eur J Pediatr. 1992 Apr;151(4):258-62.

12. Ahmed ML, Connors MH, Drayer NM, Jones JS, Dunger DB. Pubertal growth in IDDM's determined by HbA1c levels, sex, and bone age. Diabetes Care. 1998 May;21(5):831-5.

13. Pelsmaekers B, Loos R, Carels C, Derom C, Vlietinck R. The genetic contribution to dental maturation. J Dent Res. 1997 Jul;76(7):1337-40.

14. Franco A, Thevissen P, Fieuws S, Souza PHC, Willems G. Applicability of Willems models for dental age estimations in Brazilian children. Forensic Sci Int. 2013 Sep;231(1-3):401.e1-4.

15. Krailassiri S, Anuwongnukroh N, Dechkunakorn S. Relationships between dental calcification stages and skeletal maturity indicators in Thai individuals. Angle Orthod. 2002 Apr;72(2):155-66.

16. Greulich WW, Pyle SI. Radiographic atlas of skeletal development of the hand and wrist. 2nd rev. ed. Stanford: Stanford University; 1999. 272 p.

17. Nolla CM. The development of the permanent teeth. J Dent Child. 1960 Dec;27(4):254-66.

18. Birkbeck JA. Growth in juvenile diabetes mellitus. Diabetologia. 1972 Jun;8(3):221-4. 
19. Elamin A, Hussein O, Tuvemo T. Growth, puberty, and final height in children with type 1 diabetes. J Diabetes Complications. 2006 Jul-Aug;20(4):252-6.

20. Lebl J, Schober E, Zidek T, Baldis S, Rami B, Pruhova S, et al. Growth data in large series of 587 children and adolescents with type 1 diabetes mellitus. Endocr Regul. 2003 Sep;37(3):153-61.

21. Songer TJ, LaPorte RE, Tajima N, Orchad TJ, Rabin B, Eberhardt MS, et al. Height at diagnosis of insulin dependent diabetes in patients and their non-diabetics family members. Br Med J (Clin Res Ed). 1986 May 31;292(6533):1419-22.
22. Weddell LS, Hartsfield JK Jr. Dental maturity of caucasian children in the Indianapolis area. Pediatr Dent. 2011 May-Jun;33(3):221-7.

23. Lewis AB, Garn SM. The relationship between tooth formation and other maturational factors. Angle Orthod. 1960 Apr;30(2):70-7.

24. Vallejo-Bolaños E, España-López AJ. The relationship between dental age, bone age and chronological age in 54 children with short familial stature. Int J Paediatr Dent. 1997 Mar;7(1):15-7.

25. Ozerovic B. Correlation of dental and skeletal age in children with cerebral palsy. Eur J Orthod. 1980 Jan;2(3):193-5. 